\title{
Using Citation Checking of Undergraduate Honors Thesis Bibliographies to Evaluate Library Collections
}

\author{
Reba Leiding
}

This study utilizes citation checking of advanced undergraduate research papers as a method for evaluating library collections at an institution with growing undergraduate and graduate research demands. A random sample of 101 honors thesis bibliographies from the period 1993-2002 was examined for format, discipline, and local availability rates. The proportion of journal citations in relation to books increased slightly over the period, but no other clear trends emerged. The incidence of Web citations began during the period but did not steadily increase. The study highlighted specific use patterns and collection weaknesses. Results serve as a baseline for further study of the library's undergraduate user population; further citation studies are encouraged to assess continued use of online resources as the Internet and electronic technologies evolve.

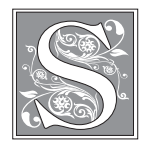

maller college libraries and undergraduate libraries at larger institutions by definition focus their collection development activities on materials that support the undergraduate curriculum. First-year writing-intensive class assignments and term papers for classes in curriculum majors require collections that cover a broad range of research topics but typically are not as comprehensive as collections at research institutions. When undergraduate students at larger institutions undertake more advanced research, they direct their research needs to the main library's stacks or its subject libraries, where their usage is assimilated into that of the overall user population.
But when two-year institutions evolve into four-year institutions, or when smaller colleges and universities change their curriculum missions to emphasize undergraduate research or add advanceddegree programs, those institutions' libraries must find ways, to say nothing of the means, of making the transition to support more advanced research. Because in larger institutions the evolving needs of advanced undergraduate research are not readily observable, few studies exist as a guide to libraries in transition on how to address this new mission. How can a library assess how adequately it is responding to such research demands? An answer may be found by analyzing bibliographic citations within existing 
examples of advanced undergraduate research.

\section{Literature Review}

The citation is a bibliographical entry in a footnote, reference list, or bibliography of a document that contains enough information (e.g., author, title, publisher, or journal title) to verify the original item. As Linda C. Smith's early review of citation analysis pointed out, the relationship between the citing document and the cited references rests on a number of assumptions, two of the most important being (1) actual use of the cited document by the citing author and (2) citation of "the best possible works... of all possible documents that could be cited." ${ }^{1}$ Given these assumptions of value and actual use, a citation can be viewed as a relevant artifact of use data. Further, citation checking of research documents and comparison of those citations with the availability of materials in a local collection offers an unobtrusive and cost-effective method of evaluating that collection's ability to support research. ${ }^{2,3}$

As Smith's and Robert N. Broadus's literature reviews noted, citation checking is a time-honored and well-studied method for determining the usefulness of collections. ${ }^{4,5}$ It is part of a broad category known as citation studies, defined by Paul H. Mosher as "any specific methodologies that use source citations or references drawn from the scholarly apparatus of articles and books as the basis for manipulation, research, and study." ${ }^{\prime 6}$ Applications for this research in this broad area have branched in several directions. Mosher noted the distinction between studies of bibliographical citations and the more "bibliometric" methodologies that examine the linking of documents through jointly cited references. ${ }^{7}$ One branch of citation-checking studies flourished from the 1970s onward as libraries responded to budgetary crises and rising journal prices. Citations in research literature within a discipline were checked in order to find a rationale for canceling subscriptions or allocating funds. Harry M. Kriz examined the ratio of books to monographs cited in master's theses for engineering and found a justification for protecting book budgets in that field. ${ }^{8}$ Checking citations in master's theses was one of the methods Christina E. Bolgiano and Mary Kathryn King used to evaluate journal collections. ${ }^{9}$ Thomas E. Nisonger checked citations in selected political science journals to evaluate the subject collection. ${ }^{10}$ Robin B. Devin and Martha Kellogg recommended using citation checking and analysis to develop a formula for a serial/monograph ratio. ${ }^{11}$ More recent studies have used citation checking of local faculty or graduate student research or of scholarly journals to evaluate subject collections in biology, psychology, polymer science, education, and interdisciplinary studies such as tourism. ${ }^{12-16}$ A study by Erin T. Smith used a sample of graduate theses and dissertation bibliographies from 1991 and 2001 to form "snapshots" of graduate research demands on the library collection. Smith's study is similar to the present one in that it analyzes citations by material type, discipline, and local availability; she used the snapshots to gauge the impact of budget constraints on collection usefulness for the library's graduate user population. ${ }^{17}$

Although numerous studies have examined research journals or bibliographies of more advanced researchers, a smaller body of studies has used citation checking to gain information about undergraduate users. Rose Mary Magrill and Gloriana St. Clair looked at differences in citation behavior by course level and in different disciplines. ${ }^{18}$ Margaret Sylvia and Marcella Lesher analyzed journal citations of undergraduate, as well as graduate, research papers to evaluate an academic library's journal collection in psychology. ${ }^{19}$ A series of studies by Philip M. Davis and Davis and Suzanne A. Cohen analyzed undergraduate term paper bibliographies to determine the effect of the Internet on citation behavior. ${ }^{20-22}$ One outcome of Davis and others was the formation of recommendations for research 
paper assignments. Karen Hovde used citation checking to evaluate the impact of library instruction on student research skills. ${ }^{23}$

Even fewer studies have analyzed undergraduate papers' bibliographies to evaluate local collection use. Kathleen E. Joswick compared local library holdings of materials cited in freshman composition papers in order to form recommendations for building collections that address undergraduate research needs. ${ }^{24}$ Joswick and Jeane Koekkoek Stierman analyzed journal citations from freshman composition papers, as well those from faculty research papers and international citation patterns, and found very little overlap; their study recommended local use studies of multiple-user types. ${ }^{25}$

\section{Background}

James Madison University (JMU) is statesupported university focused primarily on undergraduate education. The institution was founded in 1908 as a women's normal school but by the 1960s had become a coeducational institution with a broader curriculum. Since the 1970s, when the university took its present name, the number of students has nearly tripled and the university currently has an enrollment of more than 15,500 students. Although undergraduate education remains the university's primary mission, graduate enrollment is increasing along with the number of graduate programs, which now include a small number at the doctoral level. At the same time, the university is placing greater emphasis on undergraduate research and encouraging faculty to include undergraduates in their research projects. In addition, members of the teaching faculty have registered demands for collections to support faculty research through numerous user satisfaction surveys. This growing emphasis on advanced research presents a dilemma to a university library that has long focused its mission on support of an undergraduate curriculum. How can librarians evaluate how adequately current library collections support research or determine what specific needs exist?

The present study examines a particular niche of undergraduate research: honors thesis bibliographies. Although the number of students producing an honors thesis makes up a small percentage of the undergraduate population at JMU (about two percent in 2002), it can be argued that they are some of the most intensive users of library resources. Honors theses are the culmination of a serious research undertaking. For this reason, their bibliographies are more likely than those of shorter undergraduate composition papers to reliably fulfill those two assumptions underlying citation analysis methodology: that the cited material was actually used by the document's author, and that the sources used were the best possible for the purposes of his or her research. Because of the long-term nature of their projects, authors of honors theses also are less likely to limit their bibliographies to resources available only within the university's library, as is often the case with freshman composition papers. Further, as Louise S. Zipp noted in her study of graduate thesis citations, student research can serve as an indicator of research interests of their faculty advisors. ${ }^{26}$ Thus, a study of theses bibliographies also offers an efficient way to assess faculty research needs. Typically, as a matter of policy, many academic libraries collect and house copies of student theses. Even though students are a fluid population, these collections constitute a stable and accessible source of data about evolving research needs of both faculty and advanced undergraduate students.

At James Madison University, two copies of all undergraduate honors theses have been collected and housed in the library since the inception of the honors program in the 1960s. Because theses are cataloged in-house, their records show remarkable consistency in detail across years. All undergraduate theses have a unique call number, yet all share the same root call number, which facilitates 
the ability to define the entire population of records within the online catalog and move the list into a database for sample selection.

\section{Methodology}

The present study, undertaken in 2003, examined a sample of ten years' worth of thesis bibliographies from 1993 to 2002 to determine the adequacy of the collection for undergraduate research. The study also sought to detect any trends in the undergraduate research environment, such as the increased use of journals or the impact of the Internet on citation behavior. It was hypothesized that the growing availability of online indexes and

\begin{tabular}{|l|r|}
\hline \multicolumn{2}{|c|}{ TABLE 1 } \\
Number of Academic Departments \\
Represented in Study, 1993-2002 \\
\hline \hline Psychology & 15 \\
\hline Biology & 9 \\
\hline Political Science & 9 \\
\hline Integrated Science \& Technology & 8 \\
\hline History & 7 \\
\hline Anthropology and Sociology & 6 \\
\hline Business, Economics & 6 \\
\hline English & 6 \\
\hline Health Sciences & 6 \\
\hline Theatre and Dance & 6 \\
\hline Philosophy and Religion & 5 \\
\hline Art & 2 \\
\hline Chemistry & 2 \\
\hline Communications Sciences, Disorders & 2 \\
\hline Math & 2 \\
\hline Media Arts and Design & 2 \\
\hline Social Work & 2 \\
\hline Speech Communication & 2 \\
\hline Computer Science & 1 \\
\hline General Studies & 1 \\
\hline Kinesiology & 101 \\
\hline Music & \\
\hline Total & 1 \\
\hline
\end{tabular}

abstracts would lead to an increase in the percentage of journals cited as compared to monographs. Access to electronic journals also was increasing throughout the study's duration, but because citations during this early period of electronic use may not indicate whether a journal article was accessed in print or via online, no hypothesis about e-journal use was proposed. In addition, it was hypothesized that Web citations (that is, citations referring to Internet pages) would make up an increasing percentage of citations in the latter half of the 1990s.

Out of a total of 1,244 honors theses in the JMU library as of January 2002, 674 theses containing bibliographies were added to the collection between 1993 and 2002. Call numbers for this population were imported into Excel and sorted by year, and a stratified sample was chosen using Excel's random number generator. A total of 101 thesis bibliographies comprised the sample, or approximately 15 percent of the theses added in each year. Bibliographies were checked to determine the total number of citations and what types of materials were cited, such as books, journals, newspapers, primary sources (in this study defined as interviews, original correspondence, surveys, etc.), Web citations, and "other" miscellaneous sources, including government documents. Data from the bibliographies were entered in an Access database. The total number of citations per bibliography was tracked, but for purposes of analysis duplicate citations within a bibliography (that is, subsequent citations referring to a previously cited source) were counted only once. This eliminated skewing in availability rates that could occur when, for example, an anthology was cited repeatedly and reconciled differences in citation styles that used endnotes rather than a list of works cited. Citations were checked against the online catalog to determine local availability at the time. In the case of books, ownership was 
determined by the cata$\log$ date in the record; because weeding activity was minimal during the study years, current catalog records were assumed to accurately reflect holdings for the period. For journals, the volume holdings in the catalog record were checked to determine availability of particular issues when the thesis was written. Availability of full-text articles through aggregator databases was not checked for this study, with the exception of LexisNexis Academic, which the library acquired in 1999. ${ }^{27}$ Those citations not verified through the online catalog were searched in other sources such as WorldCat or Google to determine citation veracity. Data were analyzed by material type by year and by discipline to determine if any significant trends in composition of bibliographies emerged. Rates of local availability were calculated and analyzed to evaluate how well local collections serve this research population.

\section{Results}

The total number of citations in the random sample was 3,564 . The number of unique citations was 3,407 when duplicate citations were eliminated. The shortest bibliography contained two citations and the

\begin{tabular}{|c|c|c|c|c|c|c|c|c|c|c|c|c|}
\hline \multirow{14}{*}{ 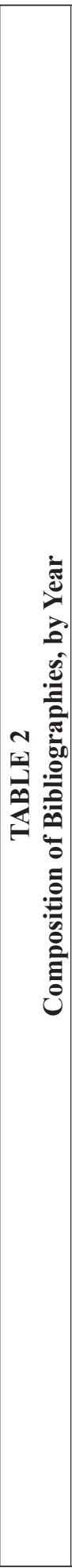 } & 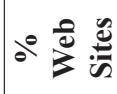 & 1 & 1 & $\mid$ & 1 & 亏े & 递 & $\begin{array}{l}0 \\
0 \\
0 \\
0\end{array}$ & 弚 & 華 & $\frac{\stackrel{2}{2}}{i}$ & iें \\
\hline & 迹 & $\mid$ & $\mid$ & | & $\mid$ & in & $\stackrel{\infty}{\sim}$ & $\stackrel{m}{r}$ & gे & o & ิ & $\overrightarrow{\widetilde{N}}$ \\
\hline & ब & in & $\frac{\partial^{\circ}}{m}$ & $\begin{array}{l}\stackrel{0}{+} \\
\stackrel{+}{1} \\
\end{array}$ & $\frac{0}{0}$ & 움 & $\begin{array}{l}\dot{0} \\
\dot{0} \\
\dot{\theta}\end{array}$ & $\begin{array}{l}\stackrel{0}{2} \\
\dot{0}\end{array}$ & 울 & 官 & $\frac{0^{0}}{6}$ & $\stackrel{\circ}{\circ}$ \\
\hline & 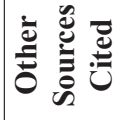 & $\hat{n}$ & $\infty$ & F & ల్లి & 로 & 文 & q & $\hat{\imath}$ & $\stackrel{\infty}{\sim}$ & $\because$ & $\vec{\sim}$ \\
\hline & 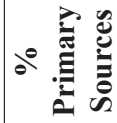 & छें & $\frac{0}{0}$ & aे & $\stackrel{2}{\stackrel{2}{i}}$ & 守 & $\begin{array}{l}\stackrel{0}{+} \\
\dot{q} \\
\dot{r}\end{array}$ & ஸें & $\begin{array}{l}\dot{0} \\
\dot{+}\end{array}$ & 1 & $\begin{array}{l}\dot{0} \\
\infty \\
\dot{m}\end{array}$ & $\begin{array}{l}\text { dे } \\
\text { ì }\end{array}$ \\
\hline & 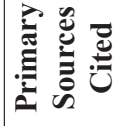 & $m$ & $\stackrel{\circ}{\sim}$ & $m$ & in & - & 이 & - & 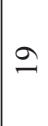 & $\mid$ & $\stackrel{0}{0}$ & $\infty$ \\
\hline & 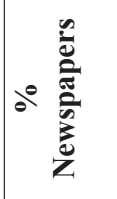 & $\begin{array}{l}\partial^{\circ} \\
= \\
=\end{array}$ & 1 & $\begin{array}{l}\infty \\
\infty \\
0 \\
0\end{array}$ & 1 & 守 & 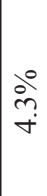 & लें & 离 & 官 & $\begin{array}{l}0 \\
\infty \\
0 \\
0\end{array}$ & $\begin{array}{l}\grave{0} \\
\infty \\
\text { ஸे }\end{array}$ \\
\hline & 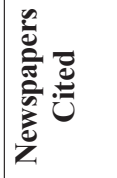 & m & $\mid$ & $\tilde{\imath}$ & $\mid$ & $a$ & 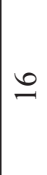 & $\because$ & 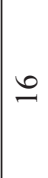 & 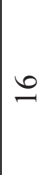 & $\sim$ & సે \\
\hline & จ를 & $\begin{array}{l}\stackrel{d}{0} \\
\dot{y} \\
i \\
m\end{array}$ & 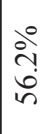 & $\frac{\dot{b}^{\circ}}{\dot{m}}$ & $\begin{array}{l}\stackrel{0}{+} \\
\dot{r} \\
\text { ले }\end{array}$ & $\begin{array}{l}\stackrel{0}{0} \\
\dot{O} \\
\text { fं }\end{array}$ & 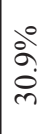 & $\begin{array}{l}\stackrel{0}{\tilde{m}} \\
\stackrel{\text { f }}{+}\end{array}$ & 官 & $\frac{\partial}{\grave{a}}$ & $\begin{array}{l}\text { oे } \\
\infty \\
i \\
\text { j }\end{array}$ & $\frac{\stackrel{\partial}{\dot{y}}}{\dot{y}}$ \\
\hline & 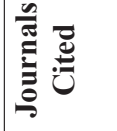 & 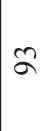 & 告 & $\hat{0}$ & बे & $\exists$ & $\Xi$ & $\hat{\sigma}$ & $\stackrel{0}{2}$ & $\stackrel{\infty}{\stackrel{\infty}{\sim}}$ & $\mathbb{t}$ & $\stackrel{\circ}{\stackrel{O}{\sigma}_{-}}$ \\
\hline & $\theta^{\circ} \frac{\frac{n}{\theta}}{0}$ & oें & $\begin{array}{l}0 \\
\dot{0} \\
0 \\
0\end{array}$ & $\begin{array}{l}\stackrel{0}{+} \\
\dot{+} \\
\dot{+}\end{array}$ & $\begin{array}{l}\stackrel{\circ}{+} \\
\dot{\sim}\end{array}$ & $\begin{array}{l}\stackrel{0}{\stackrel{0}{+}} \\
\dot{f}\end{array}$ & $\begin{array}{l}\partial^{0} \\
\infty \\
\infty \\
\infty \\
m\end{array}$ & $\frac{\stackrel{0}{+}}{\stackrel{+}{\tau}}$ & 总 & $\begin{array}{l}\stackrel{2}{i} \\
\text { iे }\end{array}$ & $\begin{array}{l}\stackrel{0}{0} \\
\infty \\
\infty \\
-1\end{array}$ & $\begin{array}{l}\stackrel{0}{0} \\
\text { in } \\
\text { in }\end{array}$ \\
\hline & 总 & 8 & 2 & t & $\widetilde{\sigma}$ & $\stackrel{\infty}{=}$ & $\stackrel{?}{ \pm}$ & $\stackrel{2}{I}$ & $\stackrel{\infty}{\infty}$ & $\hat{0}$ & gr & $\stackrel{\infty}{\infty}$ \\
\hline & 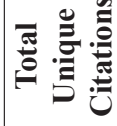 & $\stackrel{\infty}{\infty}$ & 文 & ले & ๙े & $\underset{\sim}{\mathbb{V}}$ & bे & 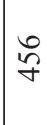 & 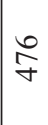 & 웅 & $\bar{\sigma}$ & m \\
\hline & Е & ळे & gे & & ๙ & 2 & $\stackrel{\infty}{2}$ & ळे & ¿े & 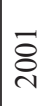 & ర్ & 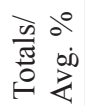 \\
\hline
\end{tabular}




\begin{tabular}{|l|c|c|}
\hline \multicolumn{3}{|c|}{ TABLE 3 } \\
Materials in "Other" Category \\
\hline \hline $\begin{array}{l}\text { Mo. of } \\
\text { Material Type }\end{array}$ & $\begin{array}{c}\text { Percent Owned } \\
\text { Times Cited } \\
\text { by JMU }\end{array}$ \\
\hline $\begin{array}{l}\text { Government documents, including those from federal, } \\
\text { state, municipal, foreign countries, etc. }\end{array}$ & 88 & $50.0 \%$ \\
\hline Law texts, court cases, bills, etc. & 66 & $96.9 \%$ \\
\hline $\begin{array}{l}\text { Reports, including annual, financial, planning, and } \\
\text { technical reports; discussion, policy, and working papers }\end{array}$ & 56 & $1.7 \%$ \\
\hline Conference papers and proceedings & 24 & $0 \%$ \\
\hline E-Resources, library & 16 & $100.0 \%$ \\
\hline Brochures, pamphlets & 11 & $0 \%$ \\
\hline Theses & 13 & $76.9 \%$ \\
\hline Videos & 8 & $50.0 \%$ \\
\hline Dissertation, Ph.D. & 6 & $0 \%$ \\
\hline Miscellaneous & 33 & $21.2 \%$ \\
\hline Total & 321 & \\
\hline
\end{tabular}

longest contained 135, with the median being 31. Twenty-two academic departments were represented in the sample. (See table 1.) Psychology, the largest department in the university, had the greatest number with a total of 15; the list as a whole showed a mix of the physical sciences, social sciences, and humanities.

Table 2 shows the composition of bibliographies by material format by year. Looking at the average percentage for all years combined, it appears that the overall reliance on books and journals is fairly evenly divided (36.3\% for books as compared to $41.4 \%$ for journals). Newspapers made up a minor part of all citations, at 3.8 percent overall and showed consistent use near that level even in later years of the study when local access to newspaper sources increased with the availability of Lexis-Nexis. Primary sources likewise were a minor source overall at 2.6 percent. The study separated out primary sources as a material type to highlight any use of the library's special collections of local historical sources; however, no theses using local primary sources were part of the sample.
The proportion of "other" sources ranged between 3 and 18 percent in the years examined and overall comprised 9.2 percent of all citations. In table 3, which also shows local availability of miscellaneous sources, government documents made up the largest component of the "other" category, accounting for 27.2 percent of all miscellaneous sources, with law texts making up an additional 20.4 percent. The library had access to 50 percent of government documents cited and 96.9 percent of law texts. The remainder of this category was dominated by grey literature, such as unpublished technical and financial reports, conference papers, or brochures, or with nonprint material.

Web citations accounted for 6.2 percent of citations overall, but no such citations appeared at all until 1997. In 1999, Web citations amounted to 16 percent of total citations (when the Internet as a new phenomenon was in fact the subject of a few theses). Interestingly, the percentage dropped to around 10 percent in the next two years and continued to decrease in the last year of the study to 7.7 percent. 


\section{Effect of Web Citations}

Because the inception of the Internet marked a watershed in the types of sources available for research, it is informative to look at the composition of bibliographies before and after Web citations began to appear in the sample bibliographies. (See table 4.) In the years of the study before Web citations, books accounted for 45.3 percent of total citations and journal citations amounted to 36.1 percent. In the years 1997-2002, Web citations accounted for nearly 10 percent of all citations, books dropped to 34.2 percent, and journals rose to 42.1 percent. If Web citations are

\begin{tabular}{|c|c|c|c|c|c|c|c|}
\hline & है & | & 1 & $\overrightarrow{\widetilde{N}}$ & $\begin{array}{l}00 \\
\dot{b} \\
0\end{array}$ & | & 1 \\
\hline & 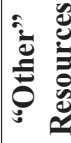 & 寻 & $\begin{array}{l}\partial^{\circ} \\
\Xi \\
\Xi\end{array}$ & $\begin{array}{l}\infty \\
\infty\end{array}$ & $\begin{array}{l}\stackrel{0}{0} \\
\grave{1} \\
\infty\end{array}$ & $\begin{array}{l}\infty \\
\infty\end{array}$ & $\frac{\partial}{a}$ \\
\hline 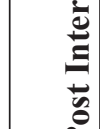 & 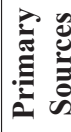 & $\stackrel{\infty}{m}$ & $\begin{array}{l}\text { ठें } \\
\dot{0}\end{array}$ & $\tilde{n}$ & iें & กี & ì \\
\hline 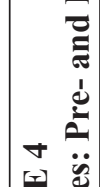 & 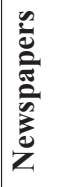 & in & $\begin{array}{l}\text { iें } \\
\text { ๆे }\end{array}$ & $\tilde{\infty}$ & $\begin{array}{l}\dot{b}^{\circ} \\
\text { ले }\end{array}$ & $\infty$ & बें \\
\hline 药 & 高 & in & $\begin{array}{l}\stackrel{0}{0} \\
\stackrel{0}{0} \\
i\end{array}$ & $\begin{array}{l}\infty \\
2 \\
2\end{array}$ & $\frac{\partial}{\stackrel{y}{y}}$ & 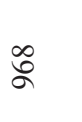 & $\begin{array}{l}\text { bे } \\
\dot{b} \\
\dot{0}\end{array}$ \\
\hline 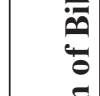 & 望 & in & $\begin{array}{l}\stackrel{0}{ } \\
\text { in } \\
\stackrel{\sigma}{0}\end{array}$ & 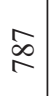 & 令 & $\underset{\infty}{\infty}$ & $\frac{\grave{n}}{\text { mे }}$ \\
\hline 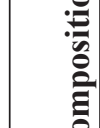 & 绨 & $\begin{array}{l}0 \\
\text { ป̂ } \\
\text { - }\end{array}$ & $\begin{array}{l}0 \\
0 \\
8 \\
8\end{array}$ & $\begin{array}{l}\infty \\
\stackrel{\text { ते }}{\mathrm{i}}\end{array}$ & ठे. & $\begin{array}{l}\hat{s} \\
\text { o } \\
\text { i }\end{array}$ & 8े. \\
\hline & & 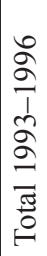 & 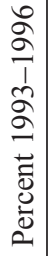 & 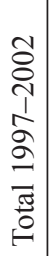 & 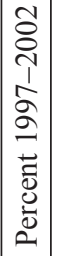 & 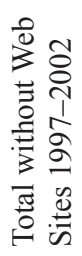 & 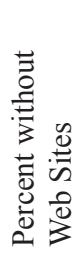 \\
\hline
\end{tabular}

removed from the equation, book citations increase $(38 \%)$ but do not reach the level found before 1997, whereas the percentage of journal citations increases to 47 percent. Although the data are not sufficient to argue that Web citations negatively impact the use of books, the generally rising percentage of journal citations when looking at pre- and post-Internet periods demonstrates that thesis authors are apparently relying more heavily on journals for their research.

\section{Local Availability}

Table 5 shows local availability of cited references by material type by year. The percentage of books held by the library ranged from 53 to 85 percent throughout the years studied, with the mean at over 65 percent. Whether this percentage can be termed adequate is a matter of opinion, but it is worth noting that the library's book budget was static for most of the period covered by the study. Availability of journals was even lower overall at 58.2 percent; however, this low percentage is a bit misleading, and an accurate analysis needs to factor in the high number of individual titles cited and the range of frequency by title. The 1,410 total journal citations referenced 729 unique journal titles. The most frequently cited journal was referenced 22 times; a total of 16 journal titles were cited ten or more times. (See table 6.) Of these frequently cited titles, the library had access to over 83 percent. (One frequent citation was a local newspaper cited heavily in a single bibliography. Without this title, the availability rate was over $86 \%$.) Over two-thirds of the journal titles in the list (494) were cited only once; of these, the library provided access to 41.5 percent on average. Newspapers, though not frequently cited (as to be expected in scholarly research), displayed the highest rates of local availability. This can be explained by the fact that even prior to access to LexisNexis, the library had extensive back files to the most frequently cited newspapers, the New York Times and the Washington Post. 
Primary sources showed the lowest rates of availability at 3.4 percent overall. Most primary sources cited in bibliographies, such as personally conducted interviews, surveys, and so on stemmed from the student author's own research, rather than use of library materials. The overall percentage of materials in the "other" category that were available locally was at $45.4 \%$, however, the availability rate for government documents was higher at $50 \%$ and law texts was $97 \%$, likely due primarily to LexisNexis.

\section{Results by Discipline}

The data also can be examined from the standpoint of discipline for collection development purposes. Theses were assigned to one of four broad disciplines based on the student's academic department, as found in the thesis catalog record: business, humanities, sciences, and social sciences. (See table 7.) Composition of bibliographies by discipline was generally as expected: theses in the humanities relied most heav-

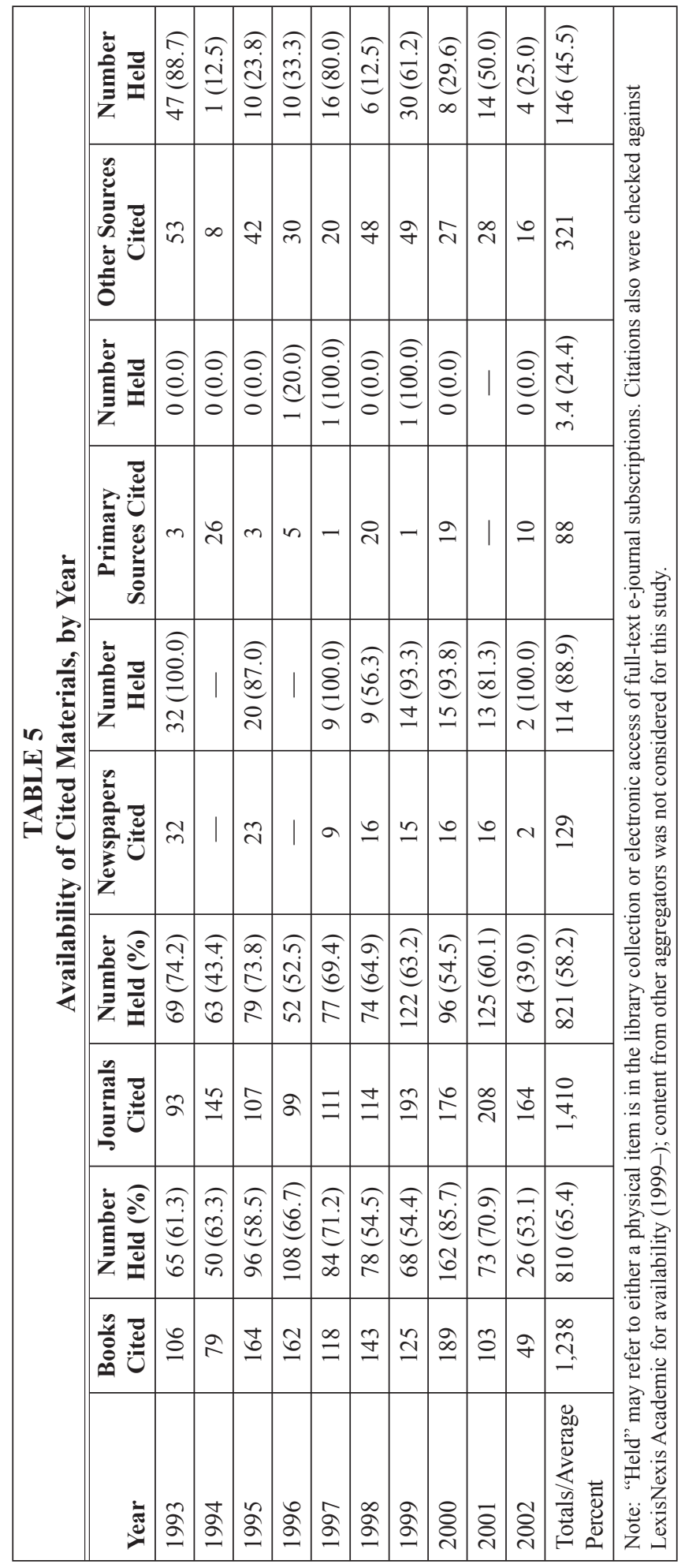




\begin{tabular}{|l|c|c|c|}
\hline \multicolumn{4}{|c|}{ TABLE 6 } \\
\hline \multicolumn{4}{|c|}{ Most Frequently Cited Journals } \\
\hline \hline Journal Title & Citations & $\begin{array}{c}\text { Held } \\
\text { Locally }\end{array}$ & $\begin{array}{c}\% \text { Held } \\
\text { Locally }\end{array}$ \\
\hline Journal of Personality and Social Psychology & 22 & 22 & $100.0 \%$ \\
\hline Science & 20 & 20 & $100.0 \%$ \\
\hline Business Week & 18 & 18 & $100.0 \%$ \\
\hline Psychological Reports & 16 & 16 & $100.0 \%$ \\
\hline Casselman Chronicles & 15 & 0 & $0 \%$ \\
\hline International Journal of Eating Disorders & 15 & 15 & $100.0 \%$ \\
\hline Nature & 15 & 15 & $100.0 \%$ \\
\hline Physical Therapy & 14 & 14 & $100.0 \%$ \\
\hline Economist & 13 & 13 & $100.0 \%$ \\
\hline Journal of Sex Research & 12 & 11 & $91.7 \%$ \\
\hline Euromoney & 11 & 11 & $100.0 \%$ \\
\hline JAMA & 11 & 11 & $100.0 \%$ \\
\hline Gerontologist & 10 & 10 & $100.0 \%$ \\
\hline Journal of Quality Technology & 10 & 0 & $0 \%$ \\
\hline New England Journal of Medicine & 10 & 10 & $100.0 \%$ \\
\hline Radiology & 10 & 0 & $0 \%$ \\
\hline Total/Avg. & 222 & 186 & $83.8 \%$ \\
\hline
\end{tabular}

ily on books $(69.3 \%)$, whereas theses in the sciences and social sciences utilized books to a lesser extent $(20.2 \%$ and $29.5 \%$, respectively). Theses in the area of business were relatively dependent on books as well, at 48.4 percent. Predictably, the highest percentage of journal citations was in the sciences $(58.8 \%)$ and second highest in the social sciences $(46.2 \%)$, whereas journal citation use in the humanities was low at 12.6 percent. Use of Web resources was the highest for business at 13.2 percent.

Some particular patterns emerge when looking at local availability of materials in terms of discipline. (See table 8.) The percentage of books held locally ranged from 68 to 72.2 percent for all disciplines except the sciences, where the local availability was lower at 40.8 percent. Likewise for journals, the local availability rate was lowest for the sciences at 44.4 percent, whereas for the other disciplines the range was from 64.9 to 70.5 percent. These figures highlight the historical weaknesses in both monograph and journal collections for the pure sciences, as would be expected at a smaller institution with a liberal arts orientation. The high cost of science materials, particularly journals, is no doubt a factor, as well. For "other" resources, the social sciences had the highest rates of local availability at 65.7 percent, reflecting the use of the government documents and local law collections by such departments as history and political science.

\section{Observations}

What implications can be seen from an analysis of thesis citation data? First of all, books remain tremendously important for researchers in the humanities and, to some extent, for business. Although the former in particular may seem an obvious point, we should recall that the library ex- 
perienced steady state budgets for much of the study period and during some years the size of book budgets eroded in the face of journal inflation. Thus, evidence for the importance of book collections serves as justification for increased funding. No overall trend emerges when looking at

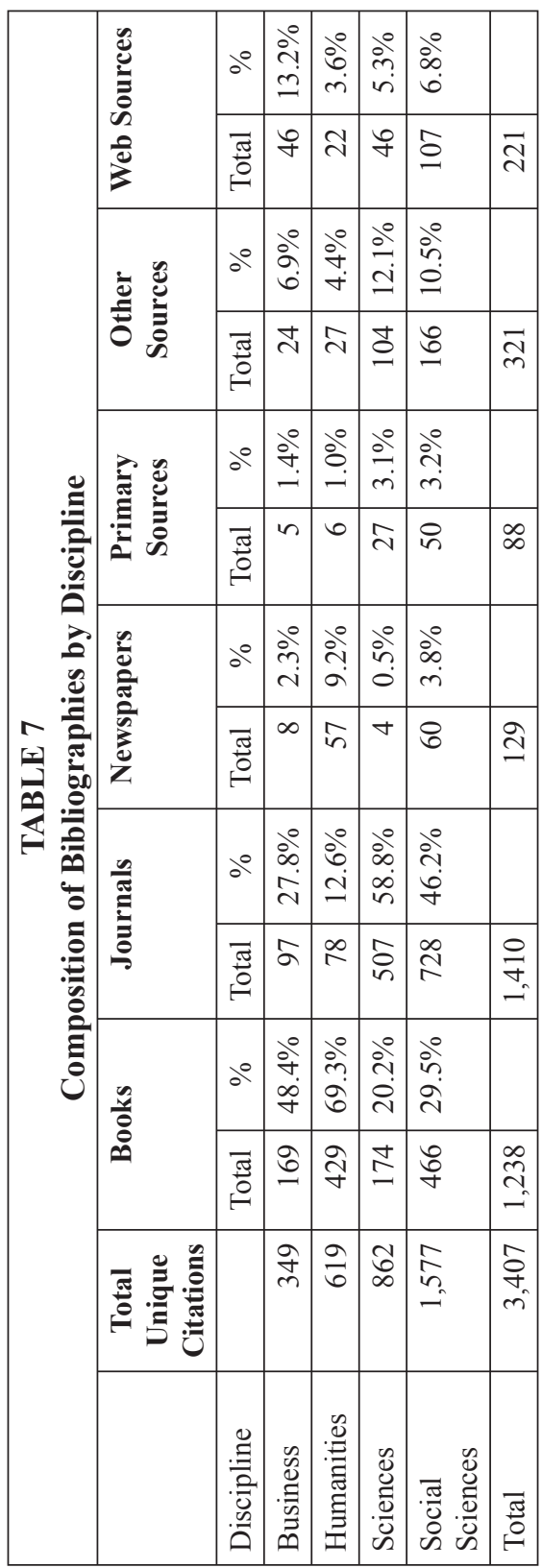

the percentage of books cited relative to journals by year in the overall composition of bibliographies, but grouping the data into pre- and post-Internet periods does provide some evidence that use of journals in undergraduate research is increasing. Access to journals is particularly important for undergraduate researchers in the sciences and social sciences, as would be expected.

Use of Web citations does not appear to be a growing trend for advanced undergraduate research. This would appear to be a somewhat surprising result given the impact of the Internet, but it parallels the findings of Davis and Cohen, and Davis's later findings. ${ }^{28-30}$ This tempering of Web citation use may reflect the involvement of faculty advisors in encouraging students to use more traditional and authoritative resources. The present study's findings can serve as a baseline in future studies to determine whether Web citations will increase as the Internet matures and what impact Internet use will have on the composition of future bibliographies.

One clear finding is the importance of government documents materials, particularly for social science research. As noted in table 3 , the overall availability rate for government documents cited at this library, which is a government document depository, was 50 percent. The growing number of government documents available online and the federal government's proposed scaling back of the document depository program will reduce the significance of libraries' physical depository collections, however. In the future, access to government documents will likely depend more on the skills of researchers - and reference librarians - in searching and navigating government Web sites.

A significant proportion of materials was unavailable locally, primarily in sources categorized as miscellaneous and primary, but perhaps most notably in the large number of journal titles cited only a few times across the years of the study. This fact points to the importance of inter- 


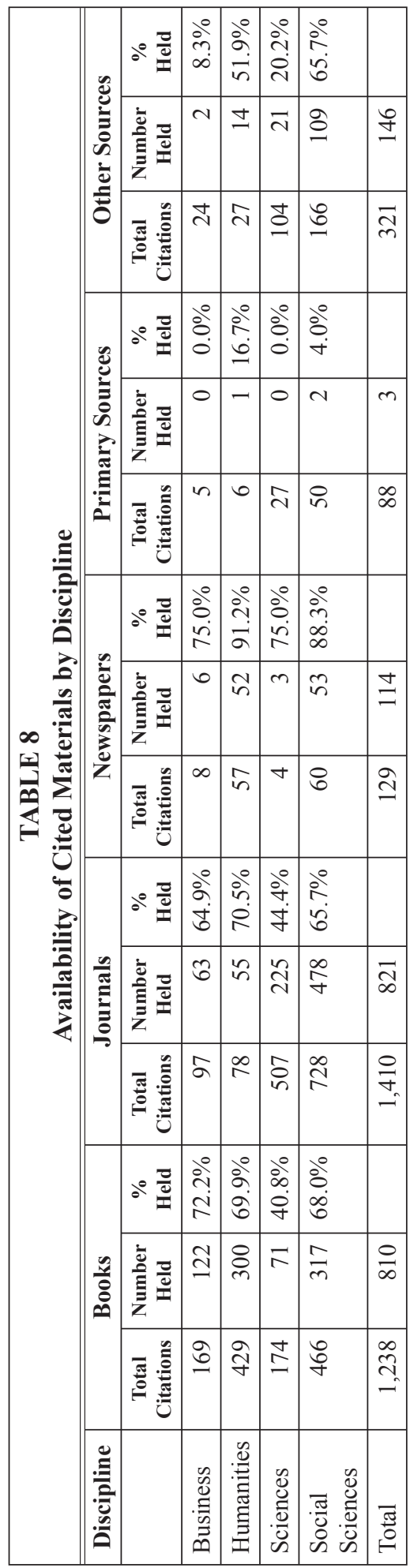

library loan (ILL) services for libraries in transition from a curricular to a research collection. ILL proves more advantageous for the undergraduate researcher working on a long-term project than for students working on shorter writing assignments, which tend to be researched at the last minute. Although ILL requests can provide important information on emerging needs for journal subscriptions, this study shows that in most cases it would not be cost efficient to add the occasionally cited title to the library collection.

\section{Conclusion}

This study found an increasing proportion of journal citations in undergraduate thesis bibliographies over time, especially for science and social science disciplines. The data did not support the hypothesis that use of Web citations in thesis bibliographies was increasing. The absence of this trend may be the result of faculty advisor intervention; faculty and students may not have viewed the Web as a scholarly resource in its early years. Also, the study did not make clear that use of Web citations had any singular impact on the composition of thesis bibliographies over time. Although the proportion of journal citations did increase relative to monographic citations in the latter portion of the period, the data do not point to specific causes for this shift. It may be due to a gradually rising number of journal subscriptions during the study period or may be the result of the eroding strength of book collections in a sustained period of steady state funding, in which case the student researchers are exhibiting at least a tendency to rely on accessibility rather than the best sources for their purposes. Or the shift may simply be a result of the particular characteristics of the sample.

At the same time, relatively low local availability rates occurred for some disciplines and material types throughout the study period. Low availability rates highlight weaknesses in the collection (a locally useful outcome of the study) but also provide a positive validation that the 
citations under study, in fact, fulfill those basic assumptions of actual use and quality of the documents cited. That is, rather than confining their research to what was locally available, the study provides evidence that the authors made an effort to obtain and use the best possible resources for their projects.

That no other strong trends or patterns emerged from the data over time demonstrates the complexity of supporting academic research needs. Even when liaison librarians or bibliographers know the research interests and patterns of individual faculty, students, or even departments, these interests and emphases can shift in response to numerous interacting factors. Traditionally, large institutions have responded to the complexity of academic research demands by using the knowledge of subject specialists and maintaining large "just-in-case" collections. A smaller academic library with limited resources must be nimble in assessing and responding to changing needs.

Locally, results of this study provide a baseline to track future trends in the use of Internet citations and online journals. Repeating the study across disciplines in future years, or focusing on theses from particular disciplines or departments, will provide further assessment of how well this institution's library resources are meeting research needs in a transitioning academic environment. Libraries at other higher education institutions whose academic mission is shifting-whether they are two-year colleges that are moving toward four-year institutions or colleges and smaller universities that are emphasizing undergraduate research, adding academic disciplines, or graduate programs - could employ methodologies such as those used in this study to evaluate how well their collections are responding to changing research demands. Librarians at these institutions are probably already aware of existing undergraduate research populations that serve as bellwethers of emerging research needs.

Several factors make this a propitious time to undertake further citation analysis studies of undergraduate research behavior. The time frame covered in this study occurs relatively early in the life of the World Wide Web and e-journal access. Style manuals by now have incorporated formats for citing online access, and librarians, faculty, and students have had time to assimilate them. This makes the task of tracking use of online materials in bibliographies more reliable. The Web continues to mature, offering an increasing number of authoritative resources. Citation studies also may provide information on how effectively student researchers use online indexes and emerging link resolver technologies. Findings from such studies will not only provide a baseline for future trends studies as technologies continue to evolve but also will contribute to what has to date been a relatively small body of research on undergraduate library users.

\section{Notes}

1. Linda C. Smith, "Citation Analysis," Library Trends 30 (summer 1981): 83-106.

2. Margaret J. Sylvia, "Citation Analysis as an Unobtrusive Method for Journal Collection Evaluation Using Psychology Student Research Bibliographies," Collection Building 17, no. 1 (1998): 20-28.

3. Thomas E. Nisonger, "A Test of Two Citation Checking Techniques for Evaluating Political Science Collections in University Libraries," Library Resources E Technical Services 27 (Apr./June 1983): 163-76.

4. Smith, "Citation Analysis."

5. Robert N. Broadus, "The Applications of Citation Analysis to Library Collection Building," in Advances in Librarianship, ed. Melvin J. Voight and Michael H. Harris, pp. 299-335 (New York: Academic Pr., 1977).

6. Paul H. Mosher, "Quality and Library Collections: New Directions in Research and Practice in Collection Evaluation," in Advances in Librarianship, ed. Wesley Simonton, pp. 211-38 (New 
York: Academic Pr., 1984).

7. Ibid., 222.

8. Harry M. Kriz, "Citation Counting and the Future of Engineering Libraries," Engineering Education 67 (Apr. 1977): 707-10.

9. Christina E. Bolgiano and Mary Kathryn King, "Profiling a Periodicals Collection," College \& Research Libraries 39 (Mar. 1978): 99-104.

10. Nisonger, "A Test of Two Citation Checking Techniques."

11. Robin B. Devin and Martha Kellogg, "The Serial Monograph Ratio in Research Libraries: Budgeting in Light of Citation Studies," College \& Research Libraries 51 (Jan. 1990): 46-54.

12. Rosalind Walcott, "Local Citation Studies: A Shortcut to Local Knowledge," Science \& Technology Libraries 14, no. 3 (1994): 1-14.

13. Margaret Sylvia and Marcella Lesher, "What Journals Do Psychology Graduate Students Need? A Citation Analysis of Thesis References," College \& Research Libraries 56 (July 1995): $313-18$.

14. Sherri Edwards, "Citation Analysis as a Collection Development Tool: A Bibliometric Study of Polymer Science Theses and Dissertations," Serials Review 25, no. 1 (1999): 11-20.

15. Laurel A. Haycock, "Citation Analysis of Education Dissertations for Collection Development," Library Resources \& Technical Services 48 (Apr. 2004): 102-6.

16. Juris Dilevko and Keren Dali, "Improving Collection Development and Reference Services for Interdisciplinary Services through Analysis of Citation Patterns: An Example Using Tourism Studies," College \& Research Libraries 65 (May 2004): 216-41.

17. Erin T. Smith, "Assessing Collection Usefulness: An Investigation of Library Ownership of the Resources Graduate Students Use," College \& Research Libraries 64 (Sept. 2003): 344-55. For a comment on Smith's methodology and response, see "Letters to the Editor," College \& Research Libraries 65 (Jan. 2004): 6-7.

18. Rose Mary Magrill and Gloriana St. Clair, "Undergraduate Term Paper Citation Patterns by Disciplines and Level of Course," Collection Management 12, no. 3/4 (1990): 25-56.

19. Sylvia, "Citation Analysis as an Unobtrusive Method."

20. Philip M. Davis, "The Effect of the Web on Undergraduate Citation Behavior: A 2000 Update," College \& Research Libraries 63 (Jan. 2002): 53-60.

21. _ " "Effect of the Web on Undergraduate Citation Behavior: Guiding Student Scholarship in a Networked Age," Portal: Libraries and the Academy 3 (Jan. 2003): 41-51. Available online at http://muse.jhu.edu/journals/portal_libraries_and_the_academy/voo3/3.1davis.pdf.

22. - and Suzanne A. Cohen, "The Effect of the Web on Undergraduate Citation Behavior 1996-1999," Journal of the American Society for Information Science and Technology 52, no. 4 (2001): 309-14.

23. Karen Hovde, "Check the Citation: Library Instruction and Student Paper Bibliographies," Research Strategies 17 (2000): 3-9.

24. Kathleen E. Joswick, "Library Materials Use by College Freshmen: A Citation Analysis of Composition Papers," College and Undergraduate Libraries 1, no. 1 (1994): 43-65.

25. — and Jeane Koekkoek Stierman, "The Core List Mirage: A Comparison of the Journals Frequently Consulted by Faculty and Students," College $\mathcal{E}$ Research Libraries 58 (Jan. 1997): $48-55$.

26. Louise S. Zipp, “Thesis and Dissertation Citations as Indicators of Faculty Research Use of University Library Journal Collections," Library Resources and Technical Services 40 (Oct. 1996): $335-42$.

27. The library had access to two databases containing some full-text articles (Gale Expanded Academic and General Business File) beginning in 1996, but their full-text content was too unstable to be verified reliably as a source of availability. Citations were checked against Lexis-Nexis Academic as a source for newspapers and law journal articles cited in theses after 1999. Rarely, students' citations indicated that the cited reference was accessed through a database, in which case the citation was counted as locally held, but in most cases citations did not include any information about electronic access.

28. Davis and Cohen, "The Effect of the Web on Undergraduate Citation Behavior 19961999."

29. Davis, "The Effect of the Web on Undergraduate Citation Behavior: A 2000 Update."

30. —— "Effect of the Web on Undergraduate Citation Behavior: Guiding Student Scholarship in a Networked Age." 


\section{DIFFERENT WAYS \\ TO PURCHASE MATERIALS FOR YOUR COLLEGE LIBRARY}

$\lceil$ Read CHOICE Magazine for hundreds of brief, critical, expert reviews of new books each month.

Every issue features essays, special features and lists of forthcoming titles.

\section{Use CHOICE Reviews on Cards.}

You'll get a complete set of reviews and nothing but the reviews! Each pack is easily divided for quick reference and portability.

9 Visit ChoiceReviews.online FREE for $\mathbf{6 0}$ days! Simply click on www. ChoiceReviews.org to gain 24/7 access to over 100,000 reviews for up to 20 authorized users. Begin your Free Trial today!

\section{Try our ChoiceReviews.online Site License}

Edition FREE for $\mathbf{6 0}$ days! Now available, our

newest $\mathrm{CHOICE}$ option eliminates passwords for quick and easy campus-wide Internet access to our entire database of reviews.

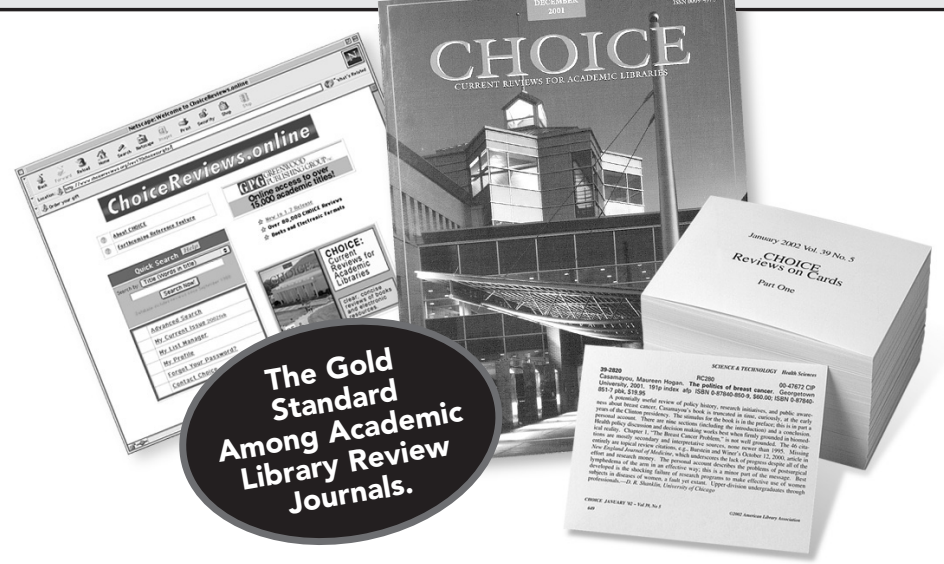

\section{DAYS ONLINE FOR FREE!}

To try ChoiceReviews.online Password or ChoiceReviews.online Site License Edition FREE for 60 days, click on www.ChoiceReviews.org. -

To subscribe to CHOICE Magazine or Reviews On Cards, contact us at www.ala.org/acrl/choice, or call (240) 646-7027. -

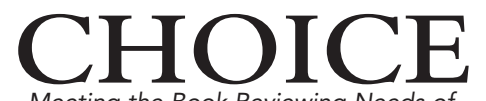

Meeting the Book Reviewing Needs of

College Libraries and Their Faculty for Over 35 Years! -

CHOICE is a publication of the Association of College \& Research Libraries, a Division of the American Library Association. 